\title{
Predicting population using the logistic growth model with slowly varying coefficients: A Multi-scale study in Bangladesh
}

\author{
SHARIF ULLAH ${ }^{1}$, Ariful Kabir ${ }^{2}$, and Hakim Khan ${ }^{2}$ \\ ${ }^{1}$ Feni University \\ ${ }^{2}$ BUET
}

September 9, 2020

\begin{abstract}
Bangladesh is one of the most overcrowded and densely populated countries in the world, where population growth is said to be worried. For the development and progression of the country, it would be essential to perceive and estimate the knowledge of the structure of the population. This article mainly focuses on the analysis and forecast of the approaching population growth of the country by considering several mathematical methods. Available census data (1981-2011) of Bangladesh applied in the well-known non-autonomous logistic population growth model where the growth rate and carrying capacity both slowly fluctuate with the time which provides several advantages to assess an approximate closed-form of the solutions. Although, most of the previous studies conducted with the population models of single species employed constant growth rate and carrying capacity. The findings of this article illuminate that the prediction and estimation of population data fairly compare with the census data of the population of Bangladesh.
\end{abstract}

\section{Hosted file}

Predicting population using the logistic growth model with slowly varying coefficients.docx available at https://authorea.com/users/357471/articles/480008-predicting-populationusing-the-logistic-growth-model-with-slowly-varying-coefficients-a-multi-scale-studyin-bangladesh

\section{Hosted file}

figure.docx available at https://authorea.com/users/357471/articles/480008-predictingpopulation-using-the-logistic-growth-model-with-slowly-varying-coefficients-a-multiscale-study-in-bangladesh 